\title{
A HEAT-BALANCE STUDY ON MGCALL GLAGIER, BROOKS RANGE, ALASKA: A CONTRIBUTION TO THE INTERNATIONAL HYDROLOGICAL DECADE
}

\author{
By Gerd Wendler and Gunter Weller \\ (Geophysical Institute, University of Alaska, Fairbanks, Alaska 997o I, U.S.A.)
}

\begin{abstract}
On the McCall Glacier, an Arctic glacier in the eastern Brooks Range, northern Alaska, a heat balance study was carried out during the summer of 1970 to investigate quantitatively the relationship between energy transfer, climatic parameters and melting processes. Considering the individual energy balance terms, it was found that radiation is the most important heat source for snow and ice melt. The melting period itself is only i i weeks long, which is quite short. The evaporation overcompensates for what little condensation occurs, and amounts to about $2 \%$ of the total ablation. Evaporation is more important in the spring, but becomes decreasingly so during the summer. The melt water which percolates into the snow-pack and refreezes at a lower level is a more effective way of transporting energy into the ground than conduction, and is of importance during the beginning of the melt period. The summer balance is considerably less energetic than over the tundra north of the Brooks Range. The main difference is a higher surface albedo, and to a lesser extent the protected nature of the glacier in a deep valley on a $\mathrm{N}-\mathrm{S}$ axis, which reduces the duration of possible sunshine by $39 \%$ in summer. These are the important factors in maintaining the McCall Glacier and other similar glaciers in an otherwise low precipitation area.
\end{abstract}

RÉsumé. Une étude du bilan thermique sur le McCall Glacier, Brooks Range, Alaska: Contribution à la Decennie Hydrologique Internationale. Sur le McCall Glacier, un glacier arctique de la Brooks Range orientale, dans le Nord de l'Alaska, on a conduit une étude du bilan thermique durant l'été 1970, en vue d'une approche quantitative des relations entre les transferts d'énergie, les paramètres climatiques et les processus de fusion. En considérant chacun des termes du bilan énergétique, on a trouvé que le rayonnement est la plus importante source de chaleur pour la fusion de la neige et de la glace. La période de fusion elle-même est longue de seulement I I semaines, ce qui est très court. L'évaporation fait plus que compenser l'apport d'une faible condensation et participe pour environ $2 \%$ à l'ablation totale. L'évaporation est plus importante au printemps mais le devient de moins en moins au cours de l'été. L'eau de fusion qui percole à travers le manteau neigeux et regèle à un niveau inférieur est un mode de transport d'énergie vers le sol plus efficace que la conduction, et se montre important pendant le début de la période de fusion. Le bilan estival est beaucoup moins énergétique que sur la toundra au Nord de la Brooks Range. La principale différence est un albédo de surface plus élevé, et, dans une moindre mesure, la position protégée du glacier dans une vallée profonde d'axe Nord-Sud qui réduit la durée possible d'illumination solaire de $39 \%$ en été. Tels sont les facteurs importants pour le maintien du McCall Glacier et d'autres glaciers similaires dans une zone par ailleurs très peu arrosée.

Zusammenfassung. Eine Untersuchung des Wärmehaushalts am McCall Glacier, Brooks Range, Alaska. Am McCall Glacier, einem arktischen Gletscher im östlichen Brooks Range Nordalaskas wurde im Sommer 1970 eine Untersuchung des Wärmehaushalts durchgeführt, um den Zusammenhang zwischen Wärmehaushalt, Klima und Ablation quantitativ zu erfassen. Aus Betrachtungen der Einzelfaktoren des Energiehaushaltes ergab sich die Strahlung als wichtigste Energiequelle für das Schmelzen von Schnee und Eis. Die Schmelzperiode ist mit i I Wochen recht kurz. Die Verdunstung überkompensiert die geringe Kondensation und trägt mit etwa $2 \%$ an der Ablation bei. Im Frühjahr kommt der Verdunstung eine grössere Bedeutung zu, welche jedoch während des Sommers abnimmt. Das Schmelzwasser, das in die Schneedecke eindringt und in tieferen Schichten wieder gefriert, ist eine wirkungvollere Art des Wärmetransports als die Wärmeleitung; besonders wichtig ist es zu Beginn der Schmelzperiode. Der sommerliche Wärmehaushalt ist wesentlich energieärmer als der der Tundra nördlich des Brooks Range. Der Hauptunterschied besteht in der grösseren Oberflächenalbedo und - zu einem geringeren Grad - in der geschützten Lage des Gletschers in einem tiefen, nordsüdlich gerichteten Tal; hierdurch wird im Sommer die mögliche Sonnenscheindauer um $39 \%$ verringert. Das sind wichtige Faktoren für die Erhaltung des McCall Glaciers und anderer ähnlicher Gletscher in einem Gebiet mit vergleichsweise geringem Niederschlag.

\section{InTRODUCTION}

McCall Glacier lies in the eastern part of the Brooks Range, in the Romanzof Mountains,

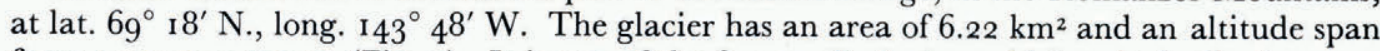
from I 340 to $2720 \mathrm{~m}$ (Fig. I). It is one of the few small glaciers which exist in the low precipitation environment of the Brooks Range at altitudes above $\mathrm{I}$ ooo $\mathrm{m}$. Most of these glaciers have northern exposures, and only a few face south, so that the energy balance, particularly its net radiation term, is unlikely to be an important factor in the presence of these glaciers. 


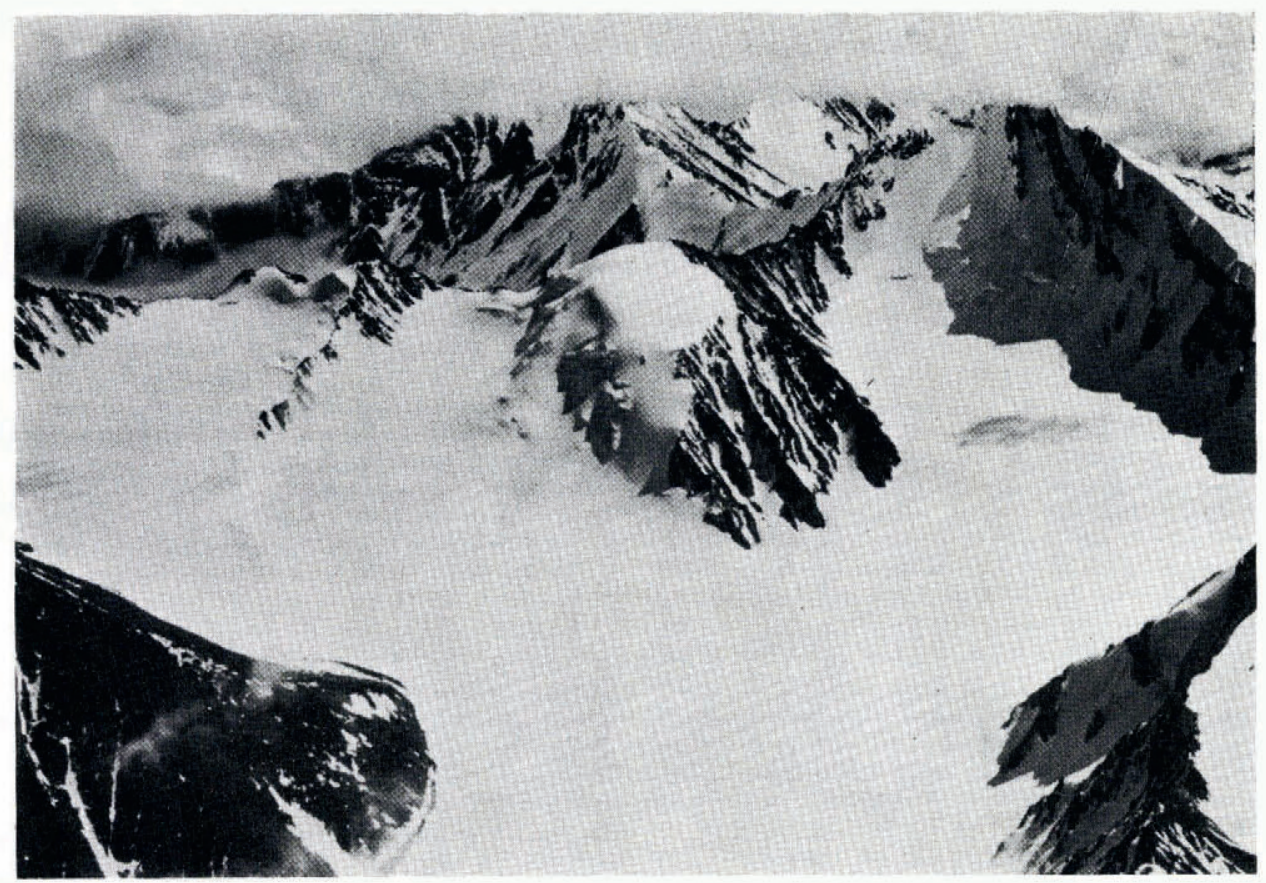

Fig. 1. Aerial view of the three accumulation basins of McCall Glacier looking towards the south.

To investigate this, a heat-balance study was carried out on the McCall Glacier in summer 1970 as part of a combined heat-, ice-, and water-balance investigation, which is being conducted under the auspices of the International Hydrological Decade (I.H.D.). McCall Glacier is the only Arctic glacier currently being studied in the United States of America, and is of special importance as it lies at the intersection of two glacier "chains" recommended for intensive study in the I.H.D.: the Arctic Circle and the American chains. It had been studied previously during the I.G.Y. (e.g. Keeler, I959; Orvig, I96r ; Orvig and Mason, I963), and by us from $1969-72$. The results of the mass and water balance for 1969 and 1970 have been published (Wendler and others, 1972, in press).

It is hoped that the present study will provide a better quantitative understanding of the relationships between energy transfer, climatic and meteorological elements, and melting processes. No attempt was made to integrate the heat balance over the whole glacier; rather, it was calculated for a single point at $1730 \mathrm{~m}$ altitude.

\section{PERiod of observation AND instrumentation}

The observations started in summer 1969 . However, as the micrometeorological instrumentation was not in good working condition until the end of the ablation season (August), the data of 1969 were not included in this study.

The observations started again on 7 April 1970, but as the ventilation system for the temperature sensors was not working before 17 May, only the period between 17 May to $3^{1}$ August was analysed. On I September the micrometeorological measurements were stopped. This period includes the whole ablation season for the altitude on the glacier at which the measurements were carried out. 
HEAT-BALANCE STUDY ON MGGAlL GLAGIER, BROOKS RANGE, ALASKA I5

The observations were made about $100 \mathrm{~m}$ from the foot of the lateral moraine, somewhat east of the middle of the glacier tongue (see Fig. 2). The glacier slopes to the north at about $7^{\circ}$ to the horizontal at this point, and this is also the general exposure of the glacier, which has a fairly simple geometry on a north-south axis.

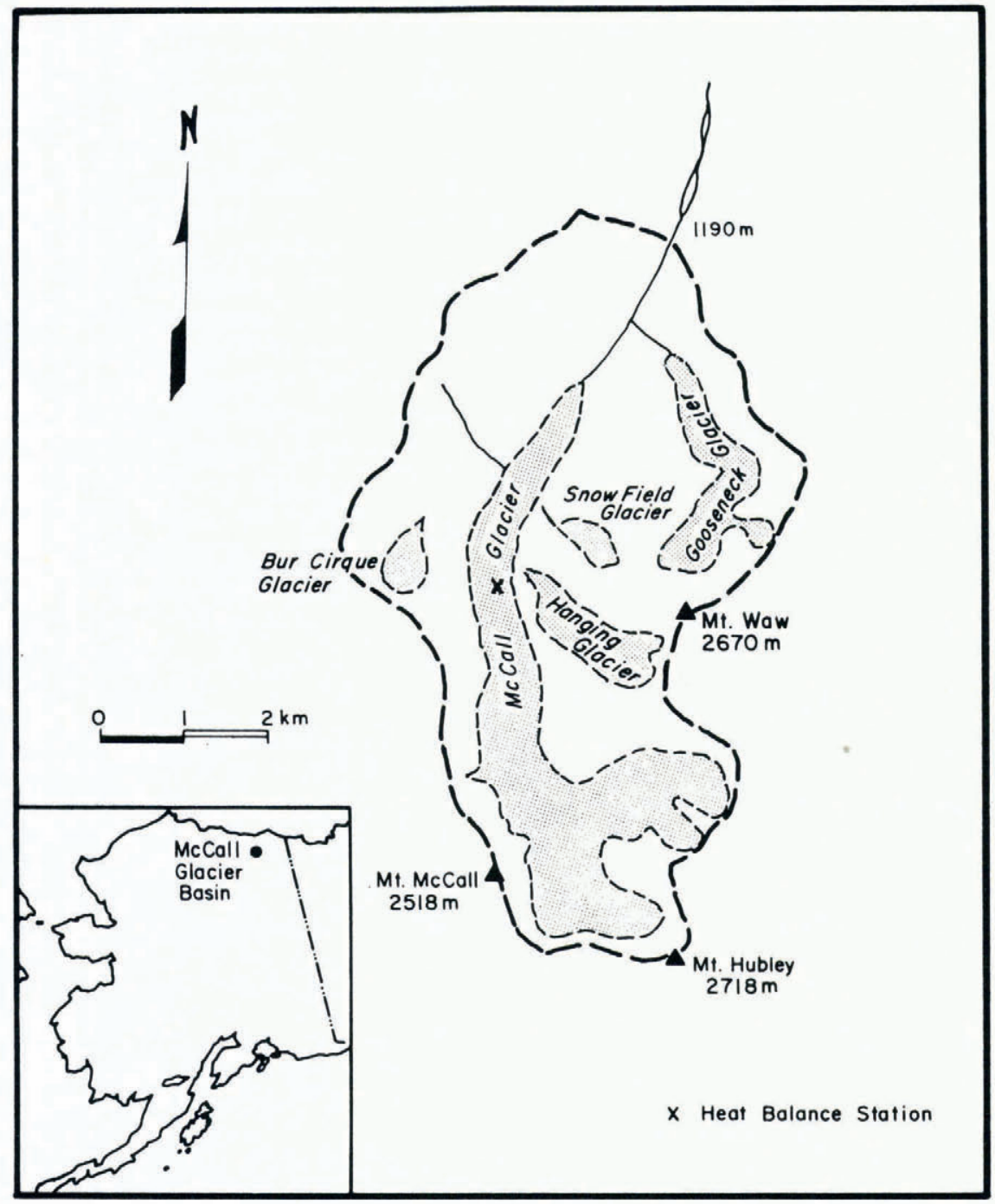

Fig. 2. Localily map of the McCall Creek Basin.

The radiation was measured with a PD-4 Davos radiometer. This instrument has four sensors, two of which are glass-shielded, the other two polyethylene-shielded, so that the incoming and reflected short-wave and the incoming and outgoing all-wave radiation can be measured independently. Long-wave incoming and outgoing radiation can then be computed as differences. The four radiative fluxes as well as the zero point and the instrument temperature were recorded continuously with "Siemens" six-channel galvanometric point recorders, which were located in a hut on the moraine about $140 \mathrm{~m}$ from the site of observations. As 
back-up for the incoming short-wave radiation, a "Belford" actinograph was utilized. The radiation measurements were calibrated in the field against a standard Linke-Feussner actinometer, which had been calibrated by its manufacturer Kipp en Zonen, Delft, Holland.

Wind speeds and temperatures were measured in a logarithmic profile $(0.5,1,2$ and $4 \mathrm{~m})$ above the glacier surface. The instrumentation was adjustable in height so that it could be at constant height above the surface (Fig. 2). "Raim" 3-cup micrometeorological wind sensors which have low starting velocities $\left(0.3 \mathrm{~m} \mathrm{~s}^{-1}\right)$ were used to measure the wind speed. For every revolution of the anemometers, an electrical pulse was transmitted to "Sodeco" digital counters located, with the rest of the recording instruments, in the hut, and the integrated number of revolutions was printed out every half hour.

The air temperatures were measured with artificially ventilated thermocouples, and the ice or snow temperatures were measured with eight thermocouples buried in the ice down to a depth of $8 \mathrm{~m}$; the output was continuously recorded on the "Siemens" point recorders. The dew points were measured with "Panasonic" aluminum oxide sensors situated at two altitudes $(0.5$ and $4 \mathrm{~m})$; these sensors change their electrical resistance with increases and decreases of the atmospheric water-vapor pressure. The ablation was measured twice daily with ten small $(5 \mathrm{~mm})$ ablation stakes situated near the micrometeorological equipment, and the snow density and stratigraphy were measured occasionally during the time when there was snow cover at the site. At a later date (17 July) a meteorological shelter, containing a thermohydrograph calibrated against an Assmann psychrometer, and a maximum and minimum thermometer, was also placed near the micrometeorological equipment. With the help of these latter instruments the heat fluxes could be estimated, at least for melting conditions, during times when the micrometeorological instrumentation was being calibrated or not in working condition.

\section{Climatology and weather conditions}

The mean and extreme climatological conditions can be obtained from Table I. The mean temperature for the latter part of May $(17-31)$ is negative $\left(-1.0^{\circ} \mathrm{C}\right)$, and even the June temperature, at $0.5^{\circ} \mathrm{C}$, is near freezing point. In July the highest mean monthly temperature $3.8^{\circ} \mathrm{C}$, was observed, while in August it became colder again $\left(1.3^{\circ} \mathrm{C}\right)$. The relative humidity

Table I. Meteorological data, McCall Glacier, summer i970

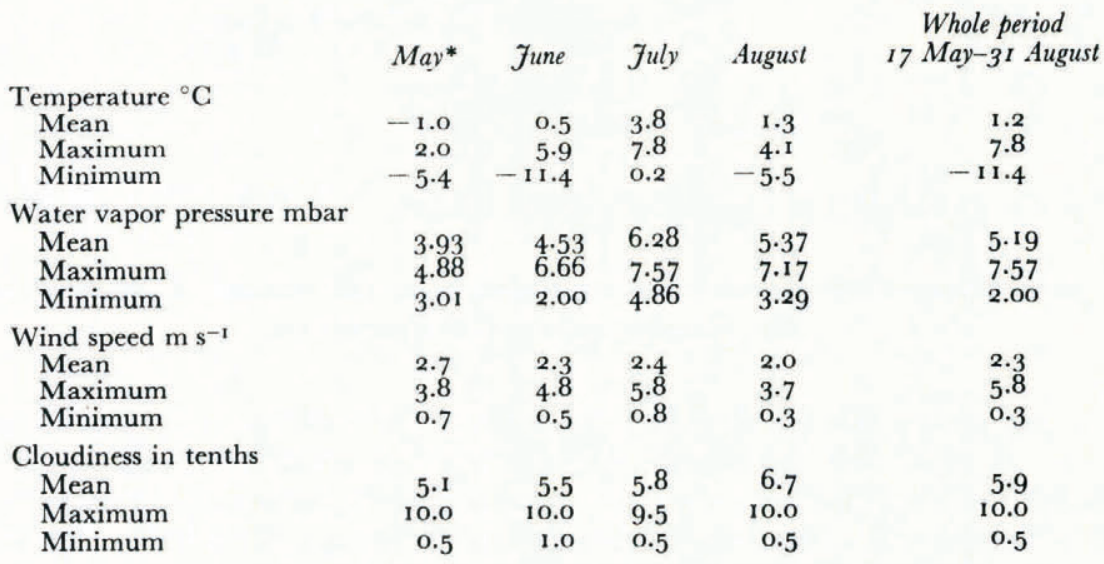

Maximum and minimum values given in the table are not the absolute maximum but represent the daily extremes.

* The observation period started on 17 May 1970. 
like the temperature, showed an increase from $69 \%$ in May to $78 \%$ in July and then increased to a maximum value of $80 \%$ in August. The wind speed did not vary substantially during the summer months, but the cloudiness showed a steady increase from May (5.r tenths) to August (6.7 tenths), a result which is in agreement with most other observations in the Arctic regions (e.g. Searby, 1968). Since no long-term climatological records exist for McCall Glacier, climatic trends can be determined from Barter Island, $90 \mathrm{~km}$ north of the glacier. Temperature means for the period I May to $3 \mathrm{I}$ August 1970 were $0.5^{\circ} \mathrm{C}$ colder than the long-term mean.

In Table II the diurnal variations of the meteorological elements are given. The highest variation in temperature was found in May, and the daily amplitude decreased steadily throughout the summer. This course was not followed by the water-vapor pressure, which showed its largest diurnal variation during the month with the highest temperature. However, this is not really surprising, as at higher temperatures the amount of water vapor the air can hold is much greater; the same temperature range-when assuming a constant relative humidity-would then result in a bigger diurnal variation in water vapor.

Table II. Diurnal variations in meteorological conditions, McCall Glacier, Summer 1970

\begin{tabular}{|c|c|c|c|c|}
\hline Period & Element & $\begin{array}{c}\text { Air } \\
\text { temperature } \\
{ }^{\circ} \mathrm{C}\end{array}$ & $\begin{array}{c}\text { Water vapor } \\
\text { pressure } \\
\text { mbar }\end{array}$ & $\begin{array}{l}\text { Wind speed } \\
\mathrm{m} \mathrm{s}^{-1}\end{array}$ \\
\hline May* & $\begin{array}{l}\text { Mean maximum } \\
\text { Mean minimum } \\
\text { Mean range }\end{array}$ & $\begin{array}{r}2.6 \\
-4.2 \\
6.7\end{array}$ & $\begin{array}{l}4.73 \\
3.13 \\
1.60\end{array}$ & $\begin{array}{l}5.2 \\
0.5 \\
4 \cdot 7\end{array}$ \\
\hline June & $\begin{array}{l}\text { Mean maximum } \\
\text { Mean minimum } \\
\text { Mean range }\end{array}$ & $\begin{array}{r}3.1 \\
-3.2 \\
6.3\end{array}$ & $\begin{array}{l}5.96 \\
3.49 \\
2.47\end{array}$ & $\begin{array}{l}5.6 \\
0.7 \\
5.0\end{array}$ \\
\hline July & $\begin{array}{l}\text { Mean maximum } \\
\text { Mean minimum } \\
\text { Mean range }\end{array}$ & $\begin{array}{l}7 \cdot 4 \\
2.3 \\
5 \cdot 1\end{array}$ & $\begin{array}{l}8.11 \\
5.13 \\
2.98\end{array}$ & $\begin{array}{l}5.8 \\
0.9 \\
4.9\end{array}$ \\
\hline August & $\begin{array}{l}\text { Mean maximum } \\
\text { Mean minimum } \\
\text { Mean range }\end{array}$ & $\begin{array}{r}3.8 \\
-0.3 \\
4.1\end{array}$ & $\begin{array}{l}6.59 \\
4.51 \\
2.08\end{array}$ & $\begin{array}{l}4 \cdot 9 \\
0.8 \\
4 \cdot 1\end{array}$ \\
\hline $\begin{array}{l}\text { Whole period } \\
\text { I } 7 \text { May-3 I August }\end{array}$ & $\begin{array}{l}\text { Mean maximum } \\
\text { Mean minimum } \\
\text { Mean range }\end{array}$ & $\begin{array}{r}4.5 \\
-1.7 \\
5.4\end{array}$ & $\begin{array}{l}6.35 \\
4.07 \\
1.28\end{array}$ & $\begin{array}{l}5.5 \\
0.7 \\
4.7\end{array}$ \\
\hline
\end{tabular}

* The observation period started on 17 May 1970.

The daily mean values of the climatic parameters are given in Figure 3. Naturally, there is a great deal of variation in these values, and it can be noted that there are extended periods during which no freezing occurs at all. Nevertheless the melting season is only 2-3 months long.

\section{Heat balance at the glacier surface}

The heat-balance equation at the glacier surface consists of the following components.

$$
(R B)_{\mathrm{s}}+(R B)_{\mathrm{L}}+S+L+B+M=\mathrm{o}
$$

with $(R B)_{\mathrm{s}}$ the short-wave radiation balance, $(R B)_{\mathrm{L}}$ the long-wave radiation balance, $S$ the sensible heat flux, $L$ the latent heat flux, $B$ the heat flux in the snow or ice, and $M$ the snow or ice melting.

All fluxes which bring energy towards the surface were considered to be positive, while the fluxes taking energy away from the surface were considered to be negative. Other fluxes, e.g. rain, were estimated, but were so small that they could be neglected. 

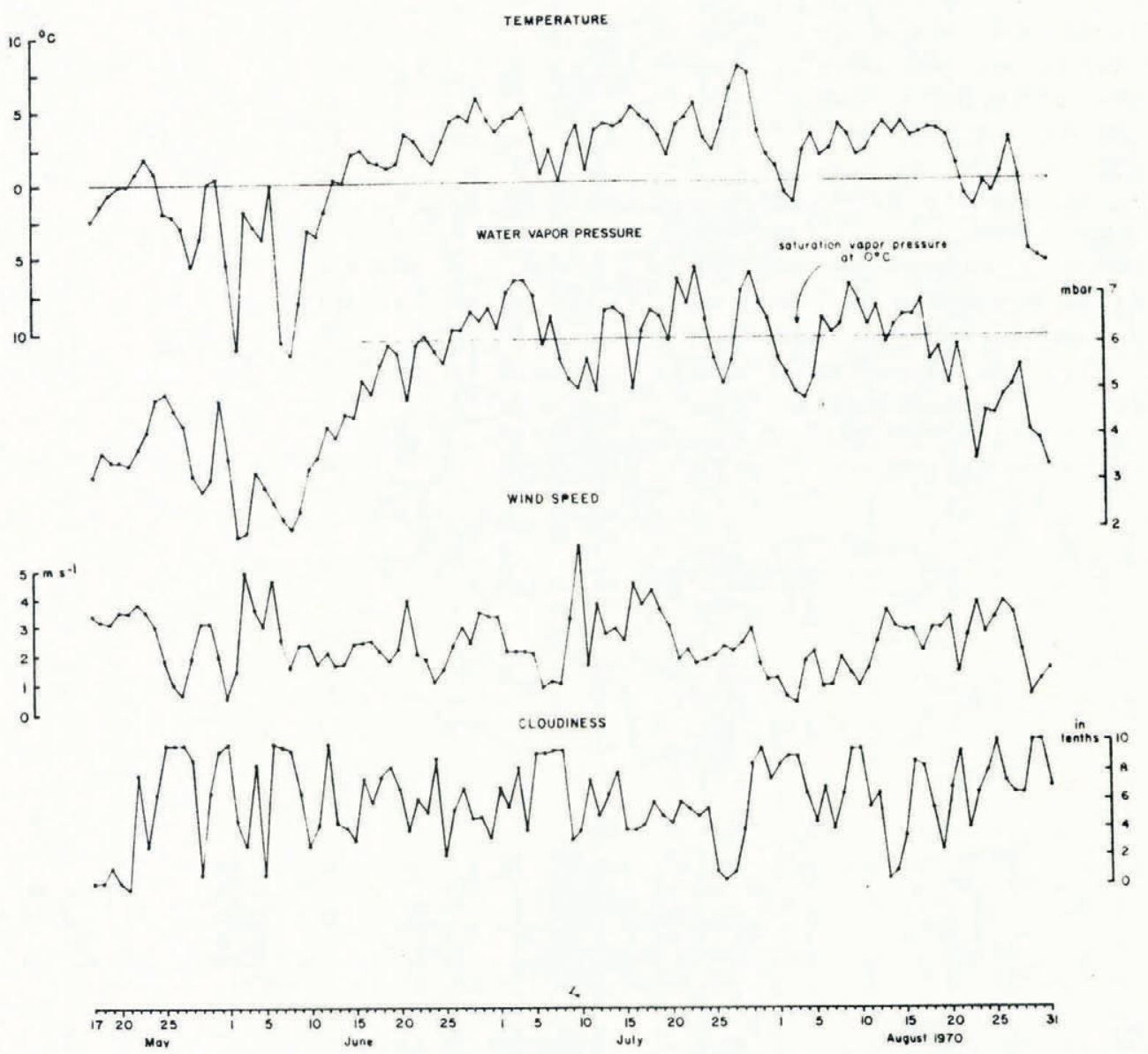

Fig. 3. Daily averages of meteorological elements, McCall Glacier, summer 1970.

A substantial potential error could be introduced by neglecting advective heat fluxes, which could not be estimated. The topography and nature of the surrounding terrain of the glacier makes it almost certain that on many occasions heat was advected to the measuring site, but the magnitude of this effect is unknown.

The period of measurements was subdivided into four phases:

(a) pre-melting period 17 May-12 June

(b) melting period, snow I 3 June-1 7 July

(c) melting period, ice 18 July-28 August

(d) post-melting period 29 August-3r August.

The distinction between these four phases is not perfect, as on some warm days in spring some melting occurs, and cold spells happen during the whole melting season; however distinctive differences are still observed during these periods. Furthermore, it should be noted that the last period consists of only three days, and therefore, the values found for this period are not necessarily typical for the early post-melting phase. 


\section{(a) The radiation balance}

A summary of the radiative fluxes which were obtained with the PD-4 Davos radiometer (Fig. 4), is given in Table III. For the pre- and post-melting periods, negative values were found for the radiation balance while they were positive during the melting period. The short-wave incoming radiation decreases during the summer. This is an effect of the increasing cloudiness coupled with the decreasing day length during the latter part of the summer. The albedo is high (nearly $80 \%$ ) for the fresh snow covers which exist during the pre- and postmelting periods and decreases during the melting period to $58 \%$ (snow) or $48 \%$ (ice) respectively. The value for ice $(48 \%)$ agrees with values found for superimposed ice (Holmgren, I97I), but is too high for glacier ice; Wendler and Ishikawa (1973) found a value of $29 \%$.

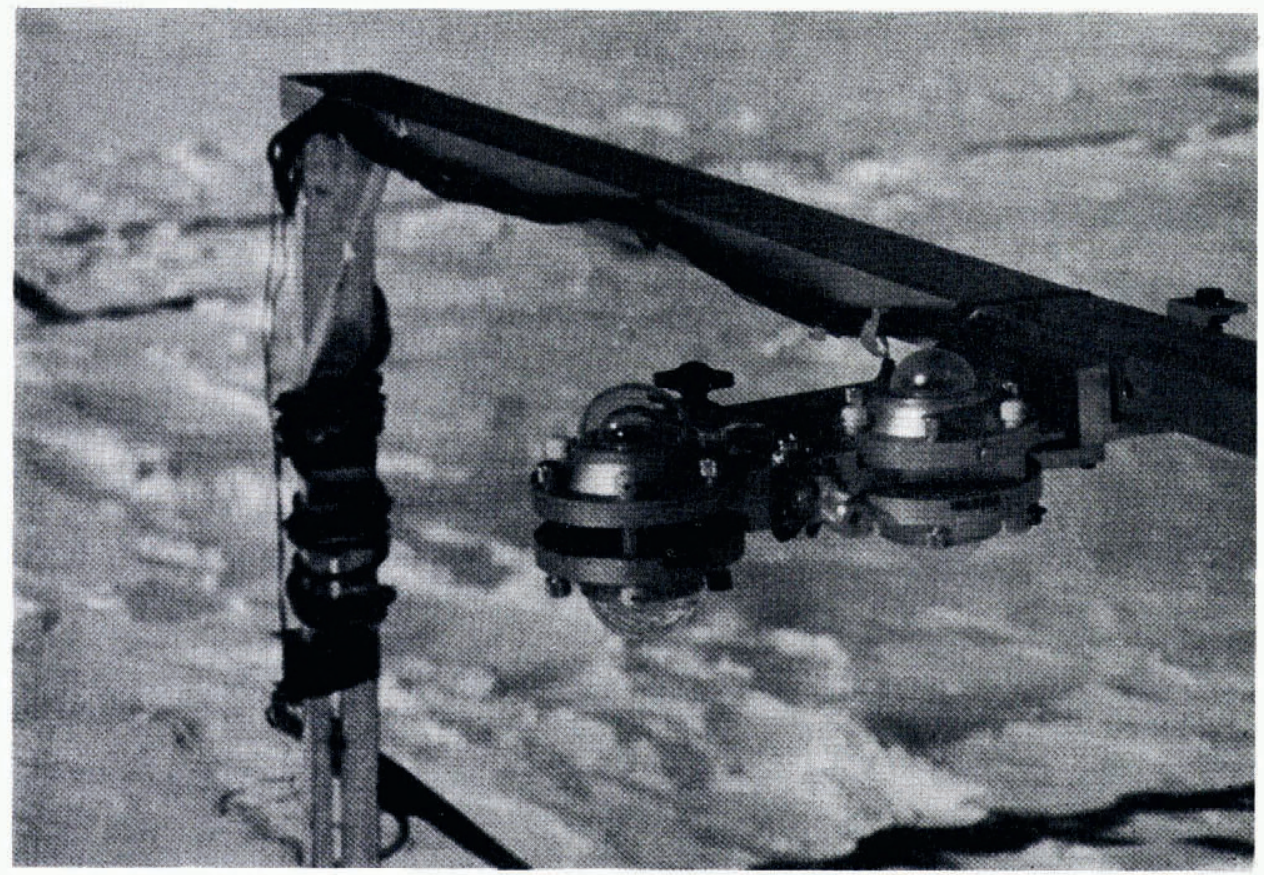

Fig. 4. PD-4 Davos radiometer. Note double glass domes (left) and Lupolen-shielded sensors (right).

The high value is explained by two snowfalls during the melting period, which raised the mean albedo for this period appreciably as shown in Figure 5. The snowfall of $\mathrm{I}$ and 2 August in particular raised the albedo substantially for about eight days. Thus new snowfalls in summer are extremely important for the mass balance, as has been pointed out before (e.g. Hoinkes, I968), both by modifying the radiation balance and by adding to the mass balance of the glacier. For example, for the total ablation period on McCall Glacier during i97o, the amount of solid precipitation added to the annual mass balance was about $10 \%$. The energy required to melt this mass was about equal to the energy lost due to the increased albedo of the new snow cover, reducing the absorbed radiation.

\section{(b) Sensible and latent heat fluxes}

The eddy fluxes were calculated from profile measurements with instruments on a $4 \mathrm{~m}$ high tower (Fig. 6) using Prandtl's relation (Lettau, 1939, 1949; Prandtl, 1956). In doing 


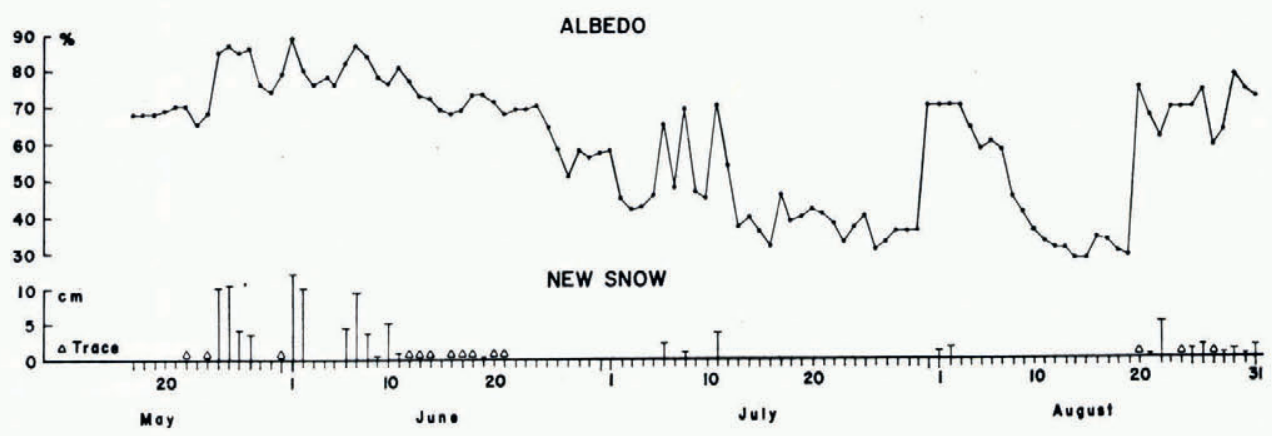

Fig. 5. Daily mean albedo and new snowfalls on McCall Glacier, summer 1970.

Table III. Radiative fluxes, MaCall Glacier, summer ig7o

\begin{tabular}{|c|c|c|c|c|c|c|c|c|c|}
\hline & \multicolumn{4}{|c|}{ Average } & \multicolumn{4}{|c|}{ Maximum } & \\
\hline & I & 2 & 3 & 4 & I & 2 & 3 & 4 & \\
\hline Short-wave incoming & $\begin{array}{l}520 \\
21.7\end{array}$ & $\begin{array}{l}496 \\
20.7\end{array}$ & $\begin{array}{c}349 \\
14.6\end{array}$ & $\begin{array}{l}243 \\
10.2\end{array}$ & $\begin{array}{l}708 \\
29.6\end{array}$ & $\begin{array}{l}747 \\
31.2\end{array}$ & $\begin{array}{l}5^{80} \\
24 \cdot 2\end{array}$ & $\begin{array}{l}256 \\
10.7\end{array}$ & $\begin{array}{l}\text { Ly d-1 } \\
\mathrm{MJ} \mathrm{m}^{-2} \mathrm{~d}^{-1}\end{array}$ \\
\hline Short-wave outgoing & $\begin{array}{l}398 \\
16.6\end{array}$ & $\begin{array}{l}292 \\
12.2\end{array}$ & $\begin{array}{r}163 \\
6.8\end{array}$ & $\begin{array}{l}195.1 \\
8.1\end{array}$ & $\begin{array}{l}55^{2} \\
23.1\end{array}$ & $\begin{array}{l}4^{89} \\
20.4\end{array}$ & $\begin{array}{l}293 \\
12.2\end{array}$ & ${ }^{205} .6$ & $\begin{array}{l}\mathrm{Lyd} \mathrm{d}^{-1} \\
\mathrm{MJ} \mathrm{m}^{-2} \mathrm{~d}^{-1}\end{array}$ \\
\hline Short-wave balance & $\begin{array}{r}122 \\
5.1\end{array}$ & $\begin{array}{r}204 \\
8.5\end{array}$ & $\begin{array}{l}186 \\
7.8\end{array}$ & $\begin{array}{l}4^{8} \\
2.0\end{array}$ & $\begin{array}{r}192 \\
8.0\end{array}$ & $\begin{array}{l}415 \\
17.3\end{array}$ & $\begin{array}{l}372 \\
15.5\end{array}$ & $\begin{array}{l}5^{1} \\
2.1\end{array}$ & $\begin{array}{l}\text { Ly d-1 } \\
M J^{-2} d^{-1}\end{array}$ \\
\hline Long-wave balance & $\begin{array}{l}-149 \\
-6.2\end{array}$ & $\begin{array}{l}-59 \\
-2.5\end{array}$ & $\begin{array}{l}-50 \\
-2.1\end{array}$ & $\begin{array}{l}-61 \\
-2.5\end{array}$ & $\begin{array}{l}-68 \\
-2.8\end{array}$ & ${ }_{1.5}^{35}$ & $\begin{array}{l}16 \\
0.7\end{array}$ & $\begin{array}{l}-57 \\
-2.4\end{array}$ & $\begin{array}{l}\mathrm{Lyd}^{-1} \\
\mathrm{MJ} \mathrm{m}^{-2} \mathrm{~d}^{-1}\end{array}$ \\
\hline All-wave balance & $\begin{array}{l}-27 \\
-1.1\end{array}$ & $\begin{array}{r}145.1 \\
6.1\end{array}$ & $\begin{array}{r}136 \\
5.7\end{array}$ & $\begin{array}{l}-13 \\
-0.5\end{array}$ & $\begin{array}{c}50 \\
2.1\end{array}$ & $\begin{array}{l}33^{8} \\
14.1\end{array}$ & $\begin{array}{l}330 \\
13.8\end{array}$ & $\begin{array}{l}-9 \\
-0.4\end{array}$ & $\begin{array}{l}\mathrm{Lyd}^{-1} \\
\mathrm{MJ} \mathrm{m}^{-2} \mathrm{~d}^{-1}\end{array}$ \\
\hline \multirow[t]{3}{*}{ Albedo } & $\begin{array}{l}77 \\
3.2\end{array}$ & $\begin{array}{l}58 \\
2.4\end{array}$ & $\begin{array}{l}4^{8} \\
2.0\end{array}$ & $\begin{array}{c}80 \\
3 \cdot 3\end{array}$ & $\begin{array}{l}89 \\
3.7\end{array}$ & $\begin{array}{l}73 \\
3 \cdot 1\end{array}$ & $\begin{array}{c}74 \\
3 \cdot 1\end{array}$ & $\begin{array}{l}8 \mathrm{r} \\
3 \cdot 4\end{array}$ & $\begin{array}{l}\mathrm{Lyd} \mathrm{d}^{-1} \\
\mathrm{MJ} \mathrm{m}^{-2} \mathrm{~d}^{-1}\end{array}$ \\
\hline & \multicolumn{4}{|c|}{ Average } & \multicolumn{4}{|c|}{ Minimum } & \\
\hline & I & 2 & 3 & 4 & I & 2 & 3 & 4 & \\
\hline Short-wave incoming & $\begin{array}{l}520 \\
21.7\end{array}$ & $\begin{array}{l}496 \\
20.7\end{array}$ & $\begin{array}{l}349 \\
14.6\end{array}$ & $\begin{array}{l}243 \\
10.2\end{array}$ & $\begin{array}{l}301 \\
12.6\end{array}$ & $\begin{array}{r}9^{2} \\
3.8\end{array}$ & $\begin{array}{l}\text { I } 8 \text { I } \\
\quad 7.6\end{array}$ & $\begin{array}{r}234 \\
9.8\end{array}$ & $\begin{array}{l}\mathrm{Ly} \mathrm{d}^{-1} \\
8 \mathrm{MJ} \mathrm{m}^{-2} \mathrm{~d}^{-1}\end{array}$ \\
\hline Short-wave outgoing & $\begin{array}{l}39^{8} \\
16.6\end{array}$ & $\begin{array}{l}292 \\
12.2\end{array}$ & $\begin{array}{r}163 \\
6.8\end{array}$ & $\begin{array}{l}195.1 \\
8.1\end{array}$ & $\begin{array}{l}255 \\
10.7\end{array}$ & $4_{1.8}^{2}$ & $\begin{array}{l}69 \\
2.9\end{array}$ & $\begin{array}{l}187 \\
\quad 7.8\end{array}$ & $\begin{array}{l}\mathrm{Lyd}^{-1} \\
\mathrm{MJ} \mathrm{m}^{-2} \mathrm{~d}^{-1}\end{array}$ \\
\hline Short-wave balance & $\begin{array}{r}\text { I } 22 \\
5.1\end{array}$ & $\begin{array}{l}204 \\
8.5\end{array}$ & $\begin{array}{r}186 \\
7.8\end{array}$ & $\begin{array}{l}4^{8} \\
2.0\end{array}$ & $\begin{array}{r}37 \\
\text { I. } 5\end{array}$ & $\begin{array}{l}50 \\
2.1\end{array}$ & $\begin{array}{c}64 \\
2.7\end{array}$ & $\begin{array}{l}47 \\
2.0\end{array}$ & $\begin{array}{l}\mathrm{Ly} \mathrm{d}^{-1} \\
\mathrm{MJ} \mathrm{m}^{-2} \mathrm{~d}^{-1}\end{array}$ \\
\hline Long-wave balance & $\begin{array}{r}-149 \\
-6.2\end{array}$ & $\begin{array}{l}-59 \\
-2.5\end{array}$ & $\begin{array}{l}-50 \\
-2.1\end{array}$ & $\begin{array}{l}-6 \mathrm{r} \\
-2.5\end{array}$ & $\begin{array}{l}-271 \\
-11.3\end{array}$ & $\begin{array}{l}-134 \\
-5.6\end{array}$ & $\begin{array}{r}-218 \\
-9.1\end{array}$ & $\begin{array}{l}-64 \\
-2 \cdot 7\end{array}$ & $\begin{array}{l}\mathrm{Lyd}^{-1} \\
\mathrm{MJ} \mathrm{m}^{-2} \mathrm{~d}^{-1}\end{array}$ \\
\hline All-wave balance & $\begin{array}{l}-27 \\
-1.1\end{array}$ & $\begin{array}{l}145 \\
6.1\end{array}$ & $\begin{array}{r}136 \\
5.7\end{array}$ & $\begin{array}{l}-13 \\
-0.5\end{array}$ & $\begin{array}{r}-2 \mathrm{I} 4 \\
-8.9\end{array}$ & $\begin{array}{l}-10 \\
-0.4\end{array}$ & $\begin{array}{l}-127 \\
-5 \cdot 3\end{array}$ & $\begin{array}{l}-17 \\
-0.7\end{array}$ & $\begin{array}{l}\text { Ly d-1 } \\
\mathrm{MJ} \mathrm{m}^{-2} \mathrm{~d}^{-1}\end{array}$ \\
\hline Albedo & $\begin{array}{c}77 \\
3 \cdot 2\end{array}$ & $\begin{array}{l}5^{8} \\
2.4\end{array}$ & $\begin{array}{l}4^{8} \\
2.0\end{array}$ & $\begin{array}{c}80 \\
3.3\end{array}$ & $\begin{array}{r}68 \\
2.8\end{array}$ & $\begin{array}{l}32 \\
1 \cdot 3\end{array}$ & $\begin{array}{r}28 \\
1.2\end{array}$ & $\begin{array}{c}79 \\
3 \cdot 3\end{array}$ & $\begin{array}{l}\text { Ly d-1 } \\
\mathrm{MJ} \mathrm{m}^{-2} \mathrm{~d}^{-1}\end{array}$ \\
\hline
\end{tabular}

I pre-melting period, 17 May-12 June.

2 melting period, snow, 13 June-I 7 July.

3 melting period, ice, 18 July-28 August.

4 post-melting period, snow, 20-31 August.

this, it was assumed that no advection takes place. Furthermore, the transfer or austausch coefficient found for momentum exchange is assumed to be identical with the transfer coefficient for sensible and latent heat exchange, which is not necessarily correct for nonadiabatic conditions (Webb, I965). During adiabatic or near-adiabatic conditions, logarithmic profiles were fitted to the wind observations to obtain a mean value for the roughness parameter $z_{0}$ for ice of $0.24 \mathrm{~cm}$. This value is in good agreement with those quoted by other 
investigators (e.g. Hoinkes, I953; Untersteiner, I957; Streten and Wendler, 1968). For snow, a mean value for the roughness parameter of $0.09 \mathrm{~cm}$ was found, which again is comparable with values found by numerous other authors under similar conditions (e.g. Liljequist, I957; Wendler and Streten, 1969).

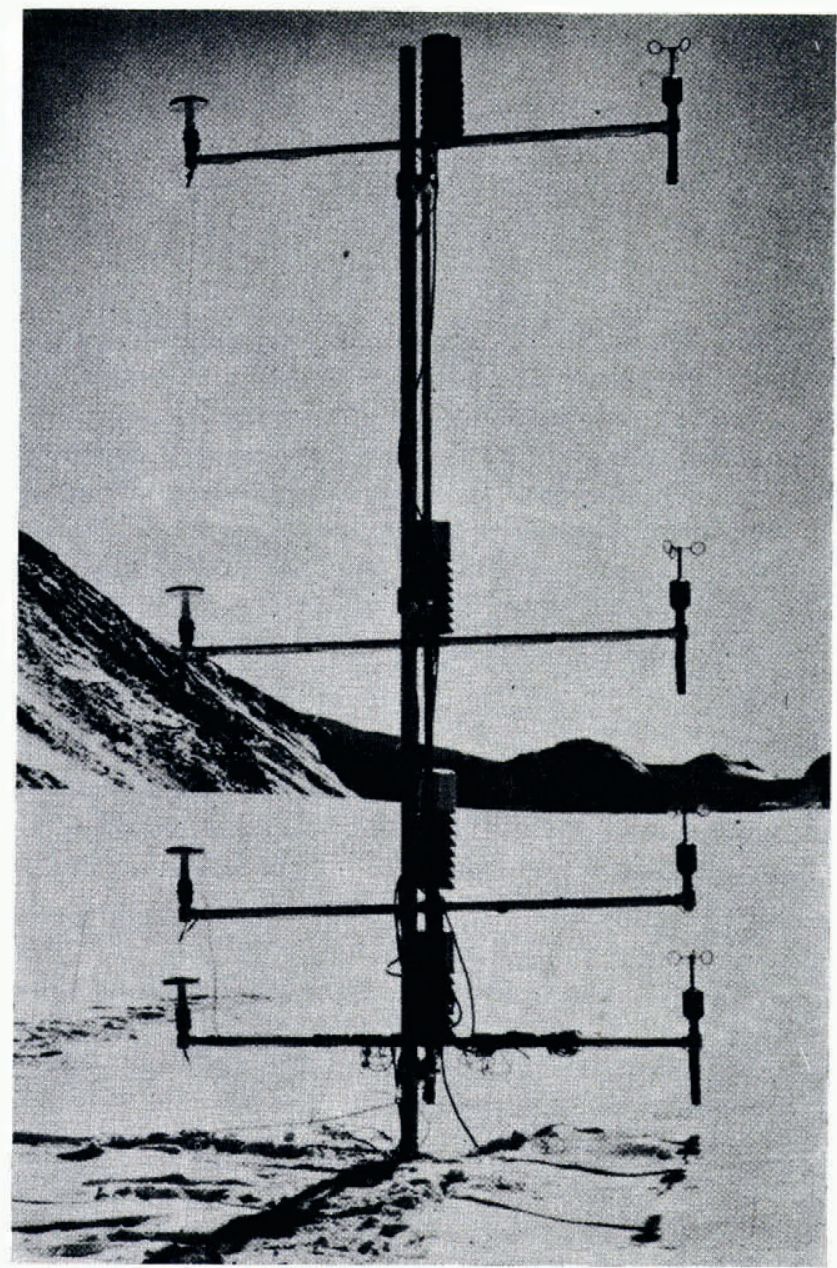

Fig. 6. Micrometeorological tower on McCall Glacier. Note the ventilated temperature sensors (left), the humidity sensors (center). The sensors shown are not the "Panasonic" sensors mentioned in the text, but are "Pernix", sensors installed at a later stage (not used during I970). Also note the wind-speed sensors (right).

For non-adiabatic conditions, correction was applied to the austausch coefficient according to Lettau (1949):

$$
A=\frac{A_{\mathrm{a}}}{(\mathrm{I}+x)^{2}}
$$

where $A$ is the austausch coefficient, $A_{\mathrm{a}}$ the austausch coefficient for adiabatic conditions, and $x$ a dimensionless stability criterion similar to the Richardson number.

The mean corrections for the four periods - pre-melting, melting snow, melting ice, and post-melting - were found to be $-7,-15,-14$ and $-31 \%$ respectively, which means, that 
owing to the generally stable air above the glacier surface, the eddy fluxes were somewhat supressed.

Applying this correction, the eddy fluxes listed in Table IV were computed from the temperature and water-vapor profiles measured above the glacier surface.

\begin{tabular}{|c|c|c|c|c|}
\hline & $\begin{array}{c}\text { Pre-melting } \\
\text { I7 May-12 June }\end{array}$ & 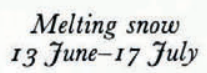 & $\begin{array}{c}\text { Melting ice } \\
\text { I } 8 \text { fuly-28 August }\end{array}$ & $\begin{array}{c}\text { Post-melting } \\
29 \text { August-3I August }\end{array}$ \\
\hline Sensible heat flux & $\begin{array}{r}+31 \\
1.3\end{array}$ & $\begin{array}{r}+51 \\
2.1\end{array}$ & $\begin{array}{r}+47 \\
2.0\end{array}$ & $\begin{array}{l}+8 \mathrm{Ly} \mathrm{d}^{-1} \\
\quad 0.3 \mathrm{MJ} \mathrm{m}^{-2} \mathrm{~d}^{-1}\end{array}$ \\
\hline Latent heat flux & $\begin{array}{l}-30 \\
-1.3\end{array}$ & $\begin{array}{l}-20 \\
-0.8\end{array}$ & $\begin{array}{l}-17 \\
-0.7\end{array}$ & $\begin{array}{l}+9 \mathrm{Ly} \mathrm{d}^{-1} \\
0.4 \mathrm{MJ} \mathrm{m}^{-2} \mathrm{~d}^{-1}\end{array}$ \\
\hline
\end{tabular}

It can be seen that the mean sensible heat fluxes were positive for all four periods. The highest values were found to be about $50 \mathrm{Ly} \mathrm{d}^{-1}\left(2 \mathrm{MJ} \mathrm{d}^{-1}\right)$ when melting occurred, the result of a strong temperature gradient above the glacier surface and relatively strong winds.

The latent-heat fluxes were negative for the first three periods, which means that evaporation exceeds condensation. The highest value was found during the pre-melting period.

The amount of evaporation decreases during the summer, and in late summer (postmelting period), the condensation exceeds the evaporation, and a positive flux towards the surface is found. This again is understandable, as the relatively warm summer air is now cooled, and can therefore hold less moisture, hence condensation takes place.

\section{(c) Heat flux in the glacier ice}

The heat flux into or out of the glacier ice could be calculated from the temperature measurements which were made at eight points down to a depth of $8 \mathrm{~m}$ and the known values of density and specific heat of snow and ice. The mean flux values obtained are shown in Table V.

Table V. Heat flux in the ice, McCall Glacier, 17 May-31 August 1970

$\begin{array}{ccccc} & \text { Pre-melting } & \text { Melting snow } & \text { Melting ice } & \text { Post-melting } \\ \text { Heat flux in the ice } & -6 & -29 & -10 & +3 \mathrm{Ly} \mathrm{d}^{-1} \\ & -0.3 & -1.2 & -0.4 & 0.1 \mathrm{MJ} \mathrm{m}^{-2} \mathrm{~d}^{-1}\end{array}$

During the first three periods, a downward flux, that is a warming of the ice or snow, was observed, while during the post-melting period, a flux towards the surface was measured. During the pre-melting period the flux is small, as snow is not a good conductor of heat. The high value for the snow-melting period is at first glance astonishing, especially as the top snow layer becomes isothermal and no heat can be transferred through it by conduction. However, the melt water percolates into the snow-pack, and part of it refreezes at a lower level, releasing its latent heat and transporting a much greater amount of heat than can be carried by conduction. In midsummer (melting ice), the heat is transported by conduction only, as ice is not permeable to water, except frequently in the uppermost layer, which fractures into a permeable honeycomb structure. In this top isothermal layer, which has a maximum thickness of about $10 \mathrm{~cm}$, heat is transferred by percolating melt water and radiation only. As ice is a better conductor than snow (ten times better than snow of density $0.3 \mathrm{Mg} \mathrm{m}^{-3}$ ) more heat is conducted during the melting periods. During the post-melting period the flux is towards the surface, but is small, owing to the presence of new, low-conductivity snow. 


\section{(d) Heat for snow and ice melt}

To melt either snow or ice, latent heat energy of $330 \mathrm{~kJ} \mathrm{~kg}^{-1}$ is required. The amount of snow or ice melt was measured carefully twice daily with ten thin $(5 \mathrm{~mm})$ ablation stakes. Owing to the effects of settling of the snow and density changes, it is very difficult to measure daily values of snow ablation accurately. A mean standard deviation of $24 \%$ was found in the daily variation of the surface level between the ro stakes.

It is easier to measure the ice ablation, but the standard deviation is nearly as large for daily values ( $18 \%$ ), since the amount of ice mélt is on the average about half that of snow melt, and hence the inaccuracy in reading the ablation stakes becomes more important.

The maximum daily ablation values of the ten stakes were about $5.1 \mathrm{~cm}$ for snow and 6 . $\mathrm{r} \mathrm{cm}$ for ice, with mean values of $3.1 \mathrm{~cm}$ snow and $1.9 \mathrm{~cm}$ ice, while during both periods cold spells occurred, in which no ablation took place at all for a $24 \mathrm{~h}$ period. In Table VI the mean and extreme values for the energy used for melting are given. It can be seen that energy available for melting increased by almost $50 \%$ after the snow cover had melted.

\begin{tabular}{|c|c|c|}
\hline & $\begin{array}{c}\text { Melting snow } \\
\text { 13 June-17 July }\end{array}$ & $\begin{array}{c}\text { Melting ice } \\
\text { I } 8 \text { fuly-28 August }\end{array}$ \\
\hline Average & $\begin{array}{l}91 \\
3.8\end{array}$ & $\begin{array}{l}{ }^{1} 34 \mathrm{Ly} \mathrm{d}^{-1} \\
5.6 \mathrm{MJ} \mathrm{m}^{-2} \mathrm{~d}^{-1}\end{array}$ \\
\hline Maximum & $\begin{array}{l}142 \\
\quad 5.9\end{array}$ & $\begin{array}{l}44^{\mathrm{I}} \mathrm{Ly} \mathrm{d}^{-1} \\
18.4 \mathrm{MJ} \mathrm{m}^{-2} \mathrm{~d}^{-1}\end{array}$ \\
\hline Minimum & $\begin{array}{l}\text { o } \\
\text { o.o }\end{array}$ & $\begin{array}{l}0 \mathrm{Ly} \mathrm{d}^{-\mathrm{t}} \\
0.0 \mathrm{MJ} \mathrm{m}^{-2} \mathrm{~d}^{-1}\end{array}$ \\
\hline
\end{tabular}

\section{(e) The heat balance as a whole}

The heat balance is shown diagrammatically in Figure 7 , and the percentage values are given in Table VII. It can be seen, not surprisingly, that the radiation balance is the largest source of heat for melting. This has been shown numerically by many previous investigations for different snow and ice terrain, e.g. on glaciers by LaChapelle (r959) and Ambach and Hoinkes (1963), on ice sheets by Ambach ( 1963 ) and for the seasonal snow cover by Gold and Williams (r96r) and Wendler (r967); summaries are given by Geiger ( 1965$)$ and Kondratyev (I969).

The study is subject to a number of errors,

(a) theoretically by the two assumptions:

(I) no advection takes place,

(2) the austausch coefficients for momentum, sensible and latent heat are identical;

and (b) by the errors in the measurements.

The assumption of no advection is likely to be inaccurate, as discussed previously, but no estimate can be made of the magnitude of the error due to this. The second assumption is also not likely to be quite valid, since neutral conditions of stability occurred rarely and the air was generally in stable equilibrium. The actual errors in measurements can be estimated better. The errors in the radiation measurements are estimated to be within $\pm 5 \%$ under normal conditions. However, owing to new snowfalls, and occasional breakdowns of the instrumentation, making interpolations necessary this accuracy probably decreased to $\pm 8 \%$. This includes the small error introduced due to the radiative fluxes having been measured on a horizontal surface, while the glacier is inclined to the horizontal at about $7 \mathrm{deg}$. The eddy fluxes are believed to be within $\pm 10 \%$. 


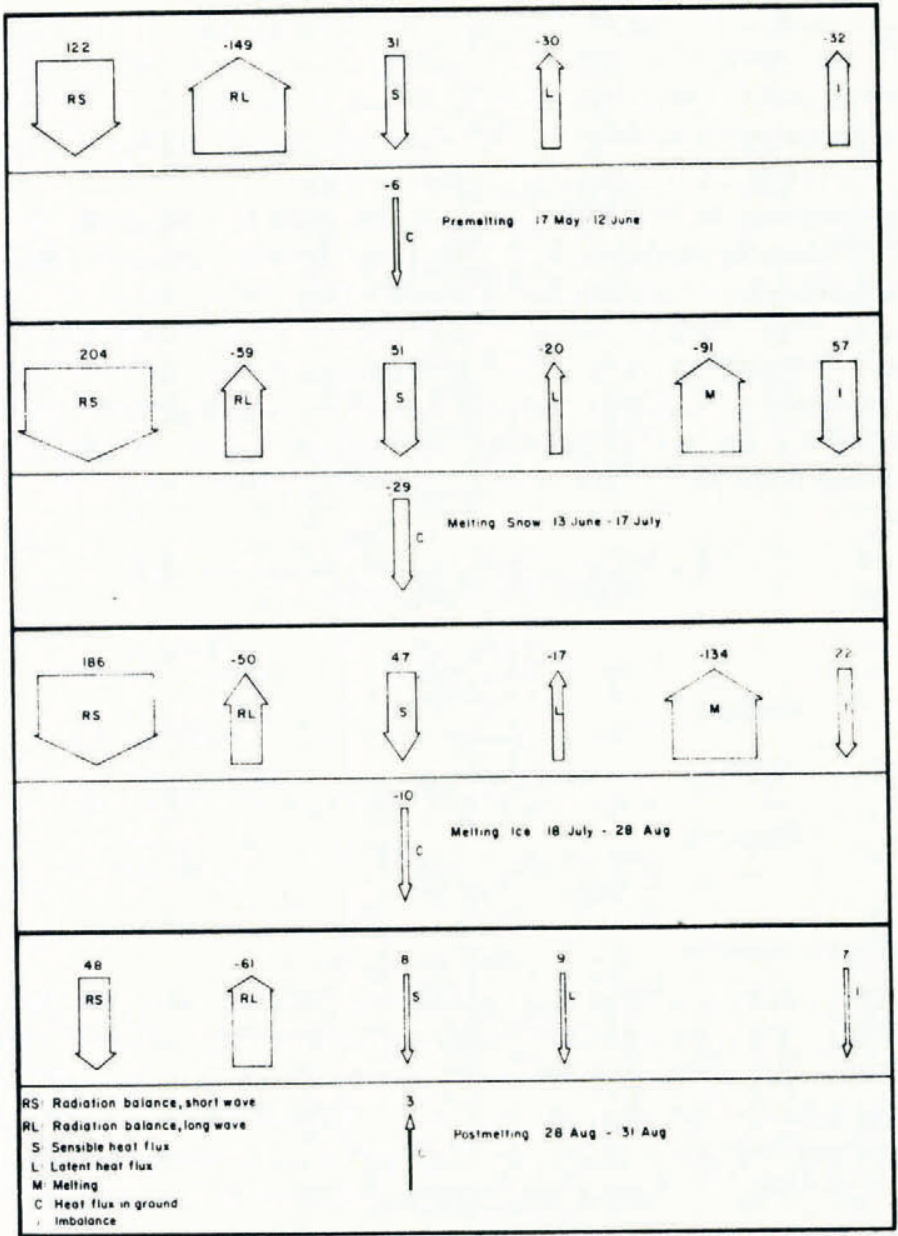

Fig. 7. Mean daily values in Langleys of the components of the heat balance for four periods of summer 1970, McCall Glacier ( 1 Langley $=41.9 \mathrm{~kJ} \mathrm{~m}^{-2}$ ).

Table VII. The components of the heat balance, McCall Glacier, 17 May-31 August 1970

(Expressed as percentages of the heat energy source)

\begin{tabular}{|c|c|c|c|c|c|}
\hline & $\begin{array}{c}\text { Pre-melting } \\
17 \text { May-I2 June }\end{array}$ & $\begin{array}{l}\text { Melting snow } \\
\text { 13 June-17 July }\end{array}$ & $\begin{array}{c}\text { Melting ice } \\
\text { I } 8 \text { July-28 August }\end{array}$ & $\begin{array}{r}\text { Post-me } \\
29 \text { August-3 }\end{array}$ & $\begin{array}{l}\text { lting } \\
\text { I August }\end{array}$ \\
\hline Radiation balance (short-wave) & +80 & +80 & +80 & +71 & $\%$ \\
\hline Radiation balance (long-wave) & -97 & -23 & -21 & -90 & $\%$ \\
\hline Sensible & +20 & +20 & +20 & +12 & $\%$ \\
\hline Latent & -20 & -8 & -7 & +13 & $\%$ \\
\hline Melting & o & -36 & -57 & o & $\%$ \\
\hline Conduction & -4 & -11 & -4 & +4 & $\%$ \\
\hline Imbalance & $-2 I$ & +22 & +11 & +10 & $\%$ \\
\hline
\end{tabular}


A certain indication of the accuracy of this study is given by the imbalance of the heat balance. Expressed as a percentage of the important heat source, the short-wave incoming radiation, the imbalance was found for the four periods: pre-melting, melting snow, melting ice, and post-melting, to be $6, \mathrm{I}$ I, 8 and $3 \%$, respectively. These values fall within the error limits quoted above. Expressed in percent of the combined heat sources, in which the balance of each contributing term is given, the imbalance appears higher: $-2 \mathrm{I}, 22, \mathrm{I}$ I and $10 \%$.

\section{Conclusions}

Several features of the relationship between mass and energy balance of McCall Glacier are of interest. As elsewhere, the most important contribution to snow and ice melt is radiation. This contribution amounts to about $60 \%$ of all energy sources. On the other hand, the magnitude of the radiation balance in summer is only about half of that of the tundra north of the Brooks Range at Barrow (Kelley and others, I964; Kelley and Weaver, I969; Weller and others, 1972). This means that while the winter values, which consist mostly of longwave radiation, are probably not greatly different for both snow-covered Arctic locations, the annual radiation balance is considerably less energetic on McCall Glacier. This is so despite the presence of fairly persistent low stratus cloud decks at Barrow, which generally cover the area north of the Brooks Range, but are below the altitude of McCall Glacier. Both high surface albedo and, to a lesser degree, the screening of the sun by the mountains surrounding the glacier, which reduces the duration of sunshine on the glacier surface by a mean of $39 \%$ in summer, combine to give a low radiation balance, favorable to the continued existence of the glacier.

In the ablation process, evaporation is responsible for only about $2 \%$ of the total ablation; the rest occurs by melting. This is a fairly typical value, reproduced quite well at other Arctic locations (Weller and others, 1972). The contribution of evaporation to the ablation is more important in spring, when it accounts for $100 \%$ of the ablation, of course, before the snow begins to melt, but its importance in actual energy and percentage terms decreases as summer progresses. When melting commences at the snow surface, the melt water percolates into the snow and refreezes at lower levels in the snow pack. This is a very effective way of transporting energy into the substratum, other than by conduction. Melting also occurs frequently in the top $10 \mathrm{~cm}$ of the ice, after the snow has melted, to create an isothermal layer across which heat is transported by melt water circulating in the loose lattice of melting ice crystals, and by radiative transfer.

In recent years, the annual mass balance of McCall Glacier has been negative in 1969 , I970, I971, and 1972, the years during which its balance was studied intensively. Fahl (unpublished) has recently shown what type of large-scale synoptic pattern over northern Alaska determines the growth of the glacier mass by precipitation. The present study has attempted to show how physical processes of energy exchange at the glacier surface determine its reduction.

\section{Acknowledgements}

The research was supported by the Atmospheric Sciences Section, National Science Foundation, under Grants GA-Ioogo and GA-28278x; logistic support was given by ONR/ NARL. The authors would like to thank Dr C. Benson, Mr S. Corbin, Dr C. Fahl and Mr D. Trabant, who participated in the field work. Mrs T. McClung helped in reducing the data, Mrs G. Shaughnessy edited the manuscript, and Dr B. Holmgren read the manuscript and made many valuable comments.

MS. received 23 July 1973 


\section{REFERENCES}

Ambach, W. 1963. Untersuchungen zum Energieumsatz in der Ablationszone des grönländischen Inlandeises

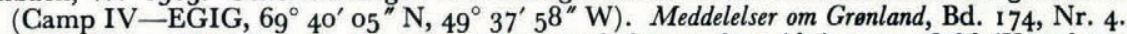

Ambach, W., and Hoinkes, H. C. 1963. The heat balance of an Alpine snowfield (Kesselwandferner, $3240 \mathrm{~m}$. , Otztal Alps, August I I-Sept. 8, 1958). Preliminary communication. Union Géodésique et Géophysique Internationale. Association Internationale d'Hydrologie Scientifique. Assemblée générale de Berkeley, $19-8-31-81963$. Commission des Neiges et des Glaces, p. 24-36.

Fahl, C. B. Unpublished. Some relationships between glaciers and climate in Alaska. [Ph.D. thesis, University of Alaska, 1973.]

Geiger, R. 1965. The climate near the ground. Cambridge, Mass., Harvard University Press.

Gold, L. W., and Williams, G. P. 1961. Energy balance during the snow melt period at an Ottawa site. Union Géodésique et Géophysique Internationale. Association Internationale d'Hydrologie Scientifique. Assemblée générale de Helsinki, 25-7-6-8 196o. Commission des Neiges et Glaces, p. 288-94.

Hoinkes, H. C. r953. Wärmeumsatz und Ablation auf Alpengletschern. II. Hornkees (Zillertaler Alpen), September 1951. Geografiska Annaler, Årg. 35, Ht. 2, p. I 16-40.

Hoinkes, H. C. 1968 . Glacier variation and weather. Fournal of Glaciology, Vol. 7, No. 49, p. 3-19.

Holmgren, B. 1971. Climate and energy exchange on a sub-polar ice cap in summer. Arctic Institute of North America Devon Island Expedition $196 \mathrm{r}-1963$. Meddelanden frän Uppsala Universitets Meteorologiska Institution, Nr. 107-12.

Keeler, C. M. 1959. Notes on the geology of the McCall Valley area. Arctic, Vol. 12, No. 2, p. 87-97.

elley, J. J., jr., and Weaver, D. F. 1969. Physical processes at the surface of the Arctic tundra. Arctic, Vol. 22, No. 4 , p. $425-37$.

Kelley, J. J., jr., and others. 1964. Radiative energy exchange over Arctic land and sea, by J. J. Kelley, [Jr.,] D. T. Bailey, B. J. Lieske. Scientific Report, Department of Atmospheric Science, University of Washington, No. 5 . (Office of Naval Research, Contract 477(24), Nr. 307-252, Part I.)

Kondratyev, K. Y. I969. Radiation in the atmosphere. New York and London, Academic Press. (International Geophysics Series, Vol. 12.)

LaChapelle, E. R. I959. Annual mass and energy exchange on the Blue Glacier. Journal of Geophysical Research, Vol. 64 , No. 4, p. $443-49$.

Lettau, H. 1939. Atmosphärische Turbulenz. Leipzig, Akademische Verlagsgesellschaft.

Lettau, H. 1949. Isotropic and non-isotropic turbulence in the atmospheric surface layer. Bedford, Mass., Geophysics Research Directorate, U.S. Air Force Cambridge Research Center. (Geophysical Research Papers, No. I.)

Liljequist, G. H. 1957. Energy exchange of an Antarctic snow-field. Wind structure in the low layer (Maudheim, $71^{\circ} 3^{\prime}$ S., $10^{\circ} 5^{\prime}$ W.). Norwegian-British-Swedish Antarctic Expedition, 1949-52. Scientific Results, Vol. 2, Part IC.

Orvig, S., ed. 1961. McCall Glacier, Alaska: meteorological observations, 1957-1958. Arctic Institute of North America. Research Paper No. 8.

Orvig, S., and Mason, R. W. 1963. Ice temperatures and heat flux, McCall Glacier, Alaska. Union Géodésique et Geophysique Internationale. Association Internationale d'Hydrologie Scientifique. Assemblée générale de Berkeley, 19-3$31-31963$. Commission des Neiges et des Glaces, p. $18 \mathrm{I}-88$.

Prandtl, L. 1956. Führer durch die Strömungslehre. 4. Auf lage. Braunschweig, F. Vieweg und Sohn.

Searby, H. W. ig68. Climates of the States. Alaska. Washington, D.C., U.S. Weather Bureau. (Climatology of the United States, 6o-49.)

Streten, N. A., and Wendler, G. 1968. The midsummer heat balance of an Alaskan maritime glacier. Journal of Glaciology, Vol. 7, No. 51, p. 431-40.

Untersteiner, N. 1957. Glazial-meteorologische Untersuchungen im Karakorum. II. Wärmehaushalt. Archiv für Meteorologie, Geophysik und Bioklimatologie, Ser. B, Bd. 8, Ht. 2, p. $137-71$.

Webb, E. K. I965. Aerial microclimate. Meteorological Monographs, Vol. 6, No. 28, p. 27-58.

Weller, G., and others. 1972. The tundra microclimate during snow-melt at Barrow, Alaska, by G. Weller, S. Cubley, S. Parker, D. Trabant and C. Benson. Arctic, Vol. 25, No. 4, p. $291-300$.

Wendler, G. 1967. Die Vergletscherung in Abhängigkeit von Exposition und Höhe und der Gebietsniederschlag im Einzugsgebiet des Pegels Vent in Tirol. Archiv für Meteorologie, Geophysik und Bioklimatologie, Ser. B, Bd. 15, Ht. 3, p. $260-73$.

Wendler, G., and others. 1972. Mass balance studies on McCall Glacier, Brooks Range, Alaska, [by] G. Wendler, C. Fahl and S. Corbin. Arctic and Alpine Research, Vol. 4, No. 3, p. 2 1 I-22.

Wendler, G., and others. In press. On the hydrology of a partly glacier-covered Arctic watershed, by G. Wendler, D. Trabant and C. [S.] Benson. [Paper presented at International Symposia on the Role of Snow and Ice in Hydrology, Banff, Canada, UNESCO Session 4, 8 September 1972.]

Wendler, G., and Ishikawa, N. 1973. Experimental study of the amount of ice melt using three different methods: a contribution to the International Hydrological Decade. Journal of Glaciology, Vol. 12, No. 66, p. 399-410.

Wendler, G., and Streten, N. A. 1969. A short term heat balance study on a Coast Range glacier. Pure and Applied Geophysics, Vol. 77, No. 6, p. 68-77. 